Campylacantha olivacea Scudd.- I have specimens from Fort Smith and Fayetteville as well as from Mackey, I. T. The earliest recorded date for its capture is August second, the latest October eighth, though doubtless some specimens survive until settled cold weather which generally does not come until after Christmas. It is a rather rare species so far as my observation goes, though it is sometimes abundant locally. It occurs in dry pastures.

Hesperotettix pratensis Scudd. - A single female was found in the summer of I 897 near Buffalo City, Marion County which I refer to this species with some hesitation. It was found in the mouth of a gully at the foot of the divide between Big Buffalo and White Rivers. Timber occurred sparsely here but vegetation was abundant. A long search in this vicinity failed to reveal any more specimens.

Dendrotettix quercus Riley.-This species is represented in my collections by one male and six females, all except one female captured near Clifty, Carroll Co., June twenty-ninth. The female referred to was taken near Elkins, Madison Co., July thirty-first.
Paratylotropidia brunneri Scudd.-This very interesting and apparently very rare species is found in Arkansas. It is represented in my collection by a single pair, male and female, captured near Clifty, Carroll Co., June twenty-ninth. I refer these specimens unwillingly to the same species as they are remarkably different in the distinctness of the lateral carinae which are obsolete in the female and very distinct in the male, and in the fastigium of the vertex, which is not perceptibly declivent in male and exceedingly prominent, while in the female it is moderately declivent and distinctly less prominent. In other respects they agree as well as male and female of the same species usually do. The single pair, male and female, known to Scudder were from Dakota and Texas respectively. As the male was an imperfect specimen, the structure of the furcula could not be given.

The Arkansas male shows. not the faintest trace of furcula and the last dorsal segment is not interrupted in the median line. The female at first glance has very much the appearance of a short winged Melanoplus bivittatus Say.

\title{
A NEW VARIETY OF CHIONASPIS FURFURUS FITCH, AND NOTES ON OTHER SPECIES.
}

\author{
BY GEO. B. KING, LAWRENCE, MASS.
}

Chionaspis furfurus Fitch. var fulvus. n. var. - Scale of female. - Shape variable, some pyriform and flat, others quite elon- gated ovoidal and convex. Length also variable; length including exuviae $3,2 \frac{1}{2}$ and 2 mm. The width of these are quite constant, 
$I_{2}^{1} \mathrm{~mm}$., while those of the convex forms are $3 \mathrm{~mm}$. long and I wide, and these are covered more or less with the epidermis of the bark of the food plant, which gives the scale the appearance of being yellowish brown instead of white as in the typical $C$. furfurus. The female agrees very well with C. furfurus, found on several other food plants in this locality. The eggs are dark purplish red. And the male scales are small and of the same normal form of the genus. The most conspicuous difference is in the lively color of the epidermis white scale of the female, giving them a very peculiar and distinct appearance from the scales of the typical $C$. furfurus.

Hab. - Lawrence, Mass., Oct. 15, 1898, on buckthorn (Rhamnus catharticus L.) The hedge infested is over 100 feet long, and to all appearances there is not a twig without some of the scales, and many of them covered with them, so much so that they are noticeable a long distance off.

Prof. Cockerell suggests that I give a few notes on other species covered with epidermis of their food plant, and has very kindly given me these references. Howardia biclavis Comst. is a species normally covered by epidermis, but Mr. Maskell has given the name var. detecta, to a form not so covered. Aspidiotus cydoniae, var. tecta Mask. is a variety covered with the epidermis of its food plant as in C. fulvus. Chionaspis minor var. timida Ckll. (MS.) is also a form covered by the epidermis of Hibiscus, found by Mr. Barber on the island of $\mathrm{An}$ tigua. Of course it is a matter of taste whether such forms as the above should be named. I believe, however, that they should be. Chionaspis furfurus var. ulmi Ckll. is a variety found on elm at Brownsville, Texas, by Prof. C. H. T. Townsend, and is not covered with epidermis.

The food plants of Chionaspis furfurus Fitch are : choke-cherry (Prunus virgini$a n a)$, black cherry $(P$. seratina), wild red cherry ( $P$. pennsylvanica), wild and culti- vated apple (Pyrus sp.), crab apple, etc., pear (Pyrus communis), peach (Persica vulgaris), Japan quince (Cydonia japonica), cherry currant var. (Ribes sp.), red flowering currant (Ribes sanguineum), European mountain ash (Larbus ancuparia). The following in Massachusetts : wild red cherry, pear, wild and cultivated apple, flowering quince (Pyrus japonica), choke-berry (Pyrus arbutifolia), shad bush (Amelanchier canadcnsis), black alder (Clethra alnifolia). The last four food plants are here recorded for the first time, and found by me; all of the others are from Dr. L. O. Howard.

Predaceous enemies. - Chilocorus bivulnerus Muls. (Walsh and Riley. W. Saunders). Hyperaspidius sp. (C. P. Gillette). Tyroglyphus malus Shimer (W. Saunders). Parasited by Alberus clisiocampae Ashm. (Howard).

Distribution.-Dr. Howard has been so. kind as to give me a complete list taken from his card catalogue.

Virginia:-Blacksburg, Buckland, Crozet, Covesville, Huntingdon valley, Monassas, Miller School, Morrisville, Maynesboro, Staunton, Tomsbrook, Vienna, Wellington, Woodstock, Warrenton, Waldrop, Winchester. Maryland:-Baltimore, Foxville. Harris Lot, Harney, Hagerstown, Still Pond, Wingate, Williamsport. Pennsylvania:Bird in Hand, Çhestnut Hills, Craley, Concordia, Floradale, Fricks, Gum Tree, Marion, North Hope, Philadelphia, Pine Grove, Rutledge, Stony Brook, Waymesboro, Yorkana. Illinois :- Cambridge, Centralia, Good Hope, Grape Creek, Hopedale, Leanderville, Loda, McLeansboro. Indiana:-Boonville, Brookville, Carthage, Jasonville, Mitchell, Terre Haute. West Virginia:-Burlington, Gerrardstown, Little Georgetown, Pow Pow, Roanoke. Northern California:-Blowing Rock, Fruitland, Greensboro, Waynesville. Ohio:-Cleveland, Horne City, Wooster, New York:-Hudson, Rye. Delaware:Dover, Newark. Kentucky:-Buckner, Valley Station. Rhode Island:- Kingston, 
Providence. Connecticut:-Nichols, Wilton. Georgia:-Augusta. Utah:-Sugar, Tennessee:-Cagle. Kansas:-Lawrence. New Jersey:- New Brunswick. Washington, D. C. Massachusetts:-Amherst, Worcester, Lawrence, Andover, Methuen. The three last are new localities.

In England, at Hereford, in 1890 , on Ribes sanguineum. (Morgan). It is also found in Canada, being included in the check-lists of inserts of the Dominion of Canada, compiled by the Natural History Society of Toronto and published in 1883 . [Henshaw].

Chionaspis furfurus has been cited as being found at New Mexico (Bull. No. 3, N. M., Agr. Exp. Sta., Jan. I89I); but Prof. Cockerell assures me that it has never been found there. Walsh in Practical Entomologist, vol. I, p. 64, I866, lists it as being very common on willow in Illinois. And Riley in American Naturalist, 1881, vol. I5, p. 487, received them on raspberry from Oxford, Miss. There is, perhaps, some doubt as to the identification of the scales on these food plants.

Chionaspis furfurus Fitch is a native species, and was first observed by Harris in I $84 \mathrm{I}$, and was named by Fitch in 1856 . It has been commonly known as the scurfy bark louse and Harris bark louse, and cited by many authors as Aspidiotus furfurus, $A$. cerasi, Coccus harrisii, Aspidiotus harrisii and Diaspis harrisii.

PosTsCrIPT. - Since the above was written, I have received the following, kindly furnished me by Prof. James Fletcher of Ottawa, Canada. Chionaspis furfurus has been received from Nova Scotia, New Brunswick, and Prince Edwards Island, and many have been imported on nursery stock. It is not an uncommon species, but at the same time by no means of frequent occurrence throughout Ontario west of this point to the Niagara Peninsula and up to Lake Huron and Georgia Bay. It has not been received from British Columbia.

\title{
DESCRIPTION OF THE LARVA OF CALOCAMPA CURVIMACULA.
}

\author{
BY HARRISON G. DYAR, WASHINGTON D. C.
}

I received these eggs through Dr. Ottolengui under another name, but the determination was corrected by breeding. The mature larva has been briefly described by Dr. Thaxter. The generic term Calocampa is utterly inapplicable to this species, as the larvae are plain, ordinary noctuids, far from "beautiful."

$E g g$. Hemispherical, rounded below, the flat base small; strongly vertically ribbed, beaded, with ring-like micropyle. There are about 40 ribs around the base, but they diminish in number upward, not confluent and are finely beaded. Diameter .8 , height $.5 \mathrm{~mm}$.

Stage I. Head rounded, pale brown, not shining; width $.4 \mathrm{~mm}$. Body slender, gait. slightly looping, the abdominal feet of joints 7 and 8 much smaller than the others. especially on joint 7 . Joint $\mathrm{i} 2$ a little enlarged. Body smooth, light gray, food visible; tubercles large, nearly black, circular, iv equidistant between iii and $v$, vi not present; setae dark, distinct, but short. Cervical shield brown; no anal plate. After feeding the larvae became pale green.

Stage II. Head pale greenish; width .6 $\mathrm{mm}$. Body long, slender, feet of joints 7 and 8 very small; not shining sordid green with narrow white dorsal, subdorsal and broader stigmatal lines, none very distinct. Tubercles minute; setae distinct, dark, normal. Segments very indistinctly annulate.

Stage III. Head whitish green, not shin. 

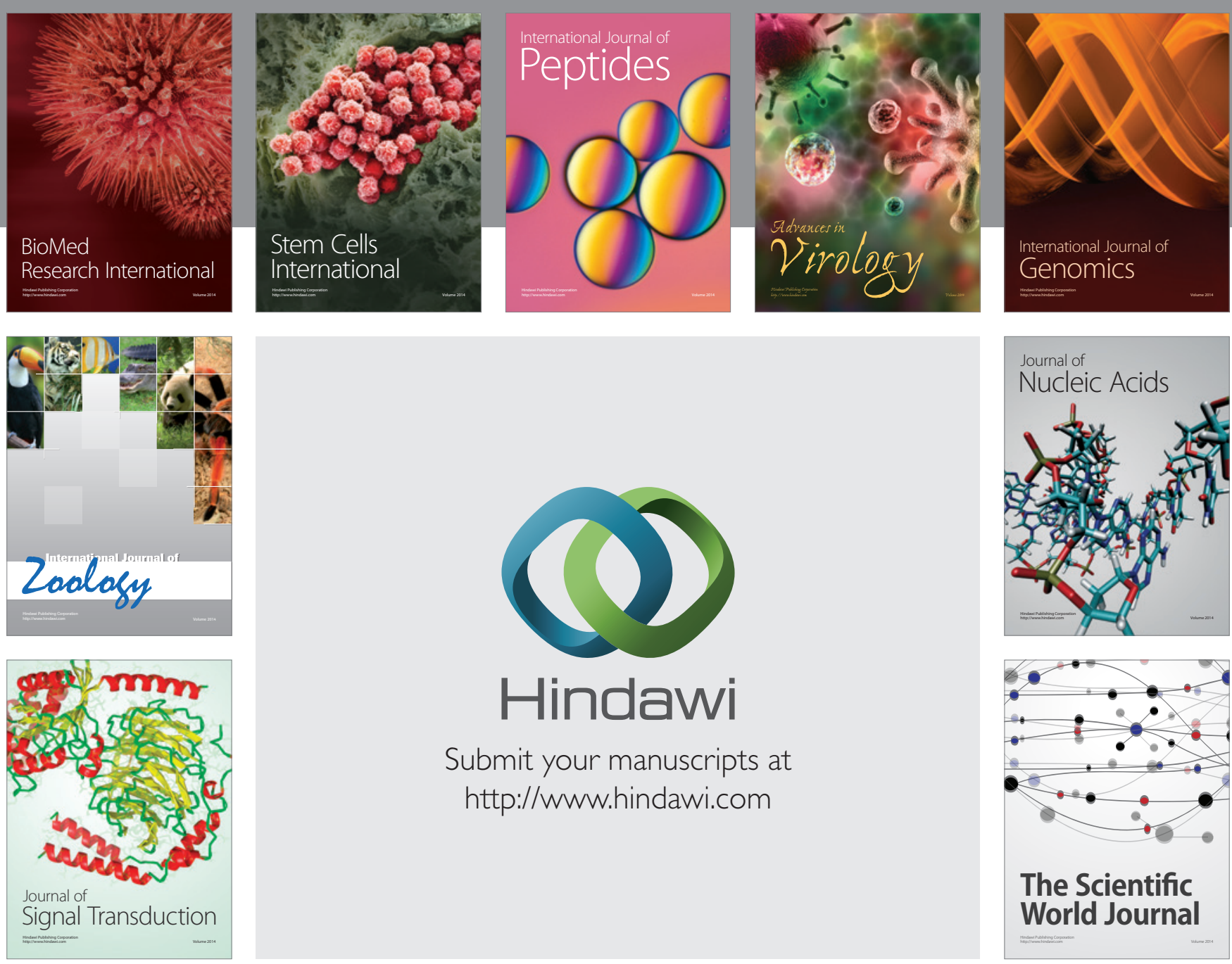

Submit your manuscripts at

http://www.hindawi.com
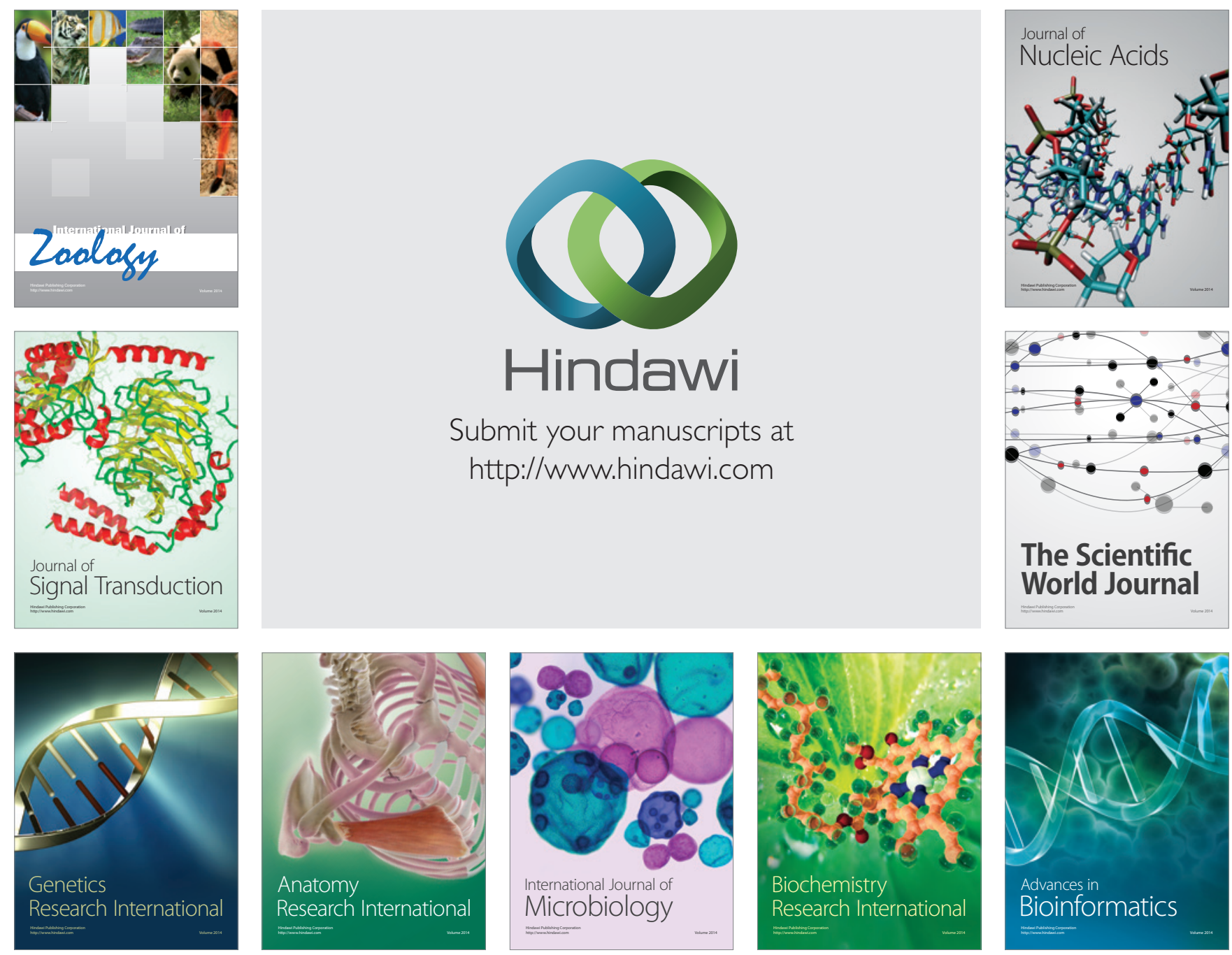

The Scientific World Journal
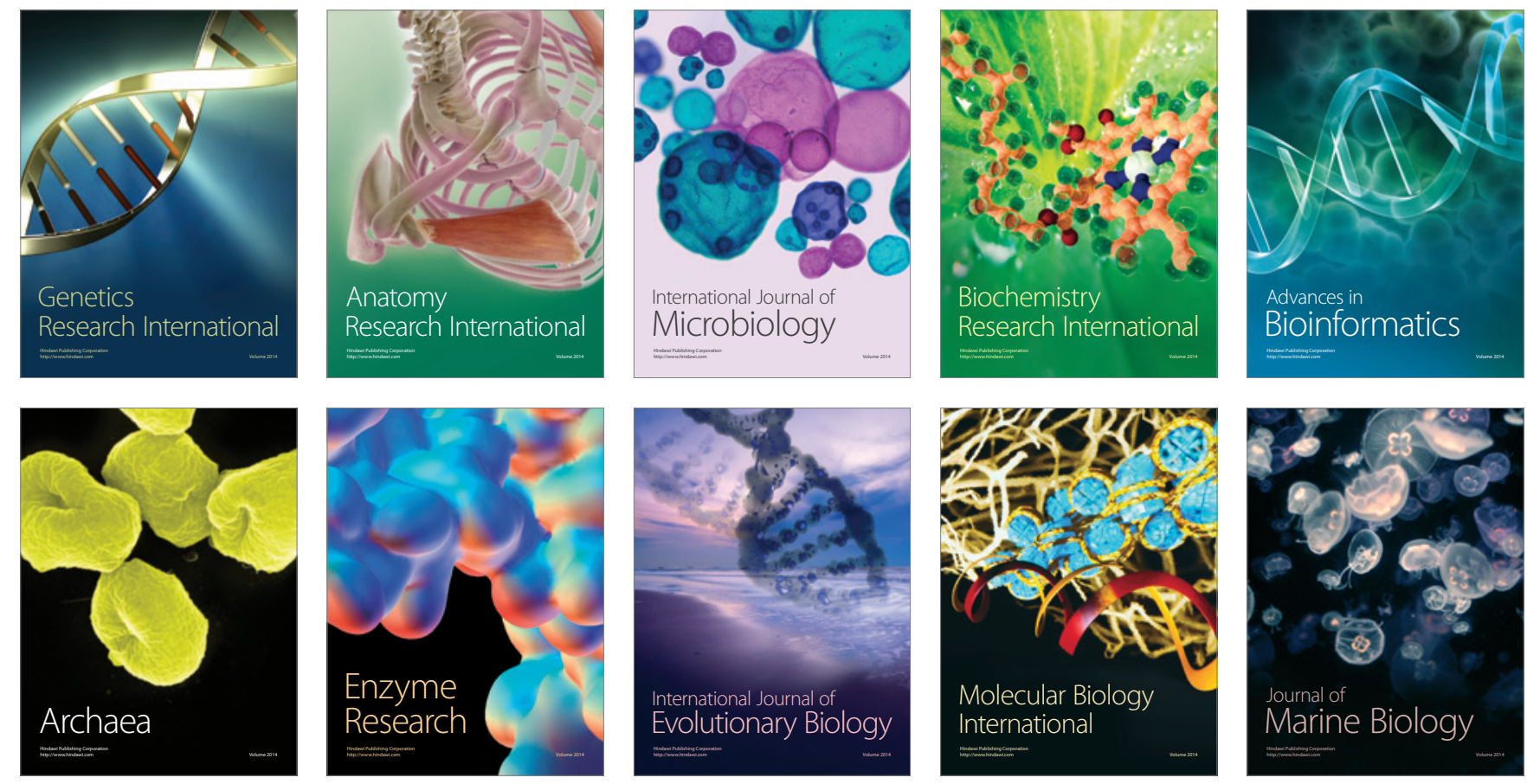